\title{
A New Modeling Approach To Prioritize Riparian Restoration To Reduce Sediment Loading in Two Virginia River Basins
}

\author{
Lisa N. Scott ${ }^{1} \cdot$ Amy M. Villamagna ${ }^{2} \cdot$ Paul L. Angermeier $^{3}$
}

Received: 28 January 2018 / Accepted: 5 June 2018 / Published online: 16 August 2018

(c) Springer Science+Business Media, LLC, part of Springer Nature 2018

\begin{abstract}
Human impact, particularly land cover changes (e.g., agriculture, construction) increase erosion and sediment loading into streams. Benthic species are negatively affected by silt deposition that coats and embeds stream substrate. Given that riparian buffers are effective sediment filters, riparian restoration is increasingly implemented by conservation groups to protect stream habitats. Limited funding and a multitude of impaired streams warrant the need for cost-effective prioritization of potential restoration actions. We created a decision-support framework for conservation agencies and aquatic resource managers to prioritize riparian restoration efforts. Our framework integrates GIS data and field surveys into a statistical model to predict instream silt from estimates of upland soil loss and riparian filtration capacity. We focus specifically on prioritizing sites in upper sections of the Roanoke and Nottoway river basins (Virginia, US) based on observed records of Roanoke logperch (Percina rex), an imperiled sediment-sensitive species. Our statistical approach examines soil characteristics, land cover, precipitation, topography, and annual soil loss estimates from the empirically derived Revised Universal Soil Loss Equation, combined with land cover-based riparian filtration capacity as potential stream habitat predictors. We found riparian filtration capacity to be a significant predictor of silt cover, while precipitation was a significant predictor of embeddedness. Spatial scale was also a factor, in that spatial variance in silt cover and embeddedness was more accurately predicted at smaller spatial extents. Ultimately, our model can be used as a prioritization tool for mitigating high siltation areas, or for protecting low soil erosion areas.
\end{abstract}

Keywords Decision support systems $\cdot$ Sediment model $\cdot$ Soil erosion $\cdot$ Riparian filtration $\cdot$ RUSLE

\section{Introduction}

Increased sediment deposition into streams caused by anthropogenic disturbance (e.g., agriculture, development, mining) degrades benthic habitat quality (Rickson

Electronic supplementary material The online version of this article (https://doi.org/10.1007/s00267-018-1078-6) contains supplementary material, which is available to authorized users.

$\triangle$ Lisa N. Scott

lnscott@plymouth.edu

1 Department of Environmental Science and Policy, Plymouth State University, MSC 63, 17 High Street, Plymouth, NH 03264, USA

2 Department of Environmental Science and Policy, Center for the Environment, Plymouth State University, Plymouth, NH 03264, USA

3 U.S. Geological Survey, Virginia Cooperative Fish and Wildlife Research Unit, Virginia Tech, Blacksburg, VA 24061, USA
2014; Bilotta and Brazier 2008) and contributes to aquatic species imperilment (Jelks et al. 2008; Haag and Williams 2013). Some of the harmful physical effects of sediment are caused by silt cover and embeddedness of stream bed substrate (Peay 2002). During low flow periods, silt particles settle out of the water column and deposit onto stream beds. Silt covers the streambed surface and embeds substrate over time as it fills in pore space and gradually buries bed material (Woo et al. 1986). For species such as the federally endangered Roanoke logperch (Percina rex) that feed by overturning gravels and pebbles, this impairs critical habitat quality (Rosenberger and Angermeier 2003).

\section{Soil Erosion Drivers}

Soil erosion is influenced by landscape characteristics and climate, such as slope, soil texture, and precipitation (Brady and Weil 2008). Precipitation events are the most significant drivers of soil erosion, as they regulate particle detachment, 
transport, and deposition (Jack et al. 2008). Raindrop impact during precipitation events dislodges soil particles, while overland flow is a main contributor to sediment transport. Upland slope affects gravitational pull on soil particles and facilitates sediment transport once particles are dislodged from the soil profile (Smith and Pun 2010). Soil texture also contributes to erosion rates; silt is the mostly easily detached and transported soil particle size (Schaetzl and Anderson 2005).

Soil erosion and transport rates are further enhanced by land use and cover changes. Forest cover converted to urban or agricultural areas increases soil exposure to raindrop impact and removes roots and vegetation that would otherwise secure soil into place; both increase soil particle detachment and transport (Holmes et al. 2004; GEI Consultants 2002). In addition to urbanization and other land alteration, climate change is another potential catalyst for soil erosion. Soil erosion rates are expected to increase over time due to predicted increases in storm intensity and raindrop impact (Christensen et al. 2007). This makes the need for effective soil erosion management and restoration of degraded sites particularly important for long-term water quality and benthic species health (Boardman and FavisMortlock 2001).

\section{Sediment Contributions from Multiple Spatial Scales}

Erosion processes contribute to instream sediment over multiple spatial scales because soil erosion occurs across an entire watershed. Sediment loading into streams can be from soil erosion at or near stream banks or it may originate from further upland where it is carried across the landscape and transported downstream (Trabucchi et al. 2013). Sediment delivery to streams depends on a number of factors, including drainage area, slope, land cover, soil texture, and hydrologic networks (De Rosa et al. 2016). Accurately modeling instream sediment requires that various sediment sources and processes be examined and represented as well as possible.

Riparian buffers, or vegetated areas adjacent to water ways, protect streams from local and upland soil erosion (Griensven 2014; Perry et al. 2015). Canopy cover from forested buffers intercepts precipitation and reduces raindrop impact on the soil surface. Woody roots from forest cover penetrate deep into the soil subsurface and grassland roots form a fibrous network, both contributing to stabilization of soil structure (Brady and Weil 2008; Dingman 2008). Higher respiration rates from vegetative buffers compared to crop fields and other land cover types also indicate higher biological activity and therefore, water infiltration enhancement during storm events from biota in forested areas (Tufekcioglu et al. 2001).

\section{Decision-Support for Riparian Restoration}

With strong evidence supporting riparian buffer effectiveness for sediment filtration, riparian revegetation is a focus of many stream restoration projects. Federal, state, and local agencies implement riparian restoration projects on public and private lands. For example, the Virginia Department of Conservation and Recreation (VADCR) produced "The Virginia Stream Restoration \& Stabilization Best Management Practices Guide" as a tool for implementing local stream restoration projects in Virginia. Tree revetments, livestock exclusion, and re-planting techniques are recommended riparian restoration strategies described in VADCR's guide (VADCR 2004).

Given the limited funding available for restoration of public lands, and Natural Resources Conservation Service (NRCS) cost share allocations to Best Management Practice (BMP) implementation on private lands, prioritization of restoration sites is necessary for cost-effective restoration. VADCR's stream restoration guide lists three steps as their method of prioritization: (1) assess stream reaches for diminished water quality, and/or biological and geomorphic condition using methods such as the Rapid Stream Assessment Technique, (2) rank sites based on severity of degradation according to stream assessment methods, and (3) prioritize sites based on feasibility of project execution, determined by site accessibility, ownership, and predicted cost. With many sites in need of restoration due to their impaired status (VADEQ 2014), critical habitat designation for endangered species (USFWS 2016), and growing urbanization (VADEQ 2014; Homer et al. 2015), an efficient and straightforward decision-support tool is needed to aid state and federal agencies and other conservation groups in effectively prioritizing sites for riparian restoration.

Decision-support frameworks can be powerful tools to provide guidance in a number of fields, and are potentially effective aids in resource management (Matthies et al. 2007). Decision-support itself is aimed at top-level decision-makers, while the framework, or steps taken to reach the final decision-making, can be implemented by any level of stakeholder. These frameworks are most useful when they have the flexibility to be applied across a range of situations. The target audience for a decision-support framework is typically a management-driven organization (Sprague Jr. 1980).

\section{Study Overview}

Our study addressed water quality issues by constructing a decision-support framework to prioritize riparian restoration for conservation agencies. We explored the hypothesis that modeled estimates of upland soil loss and riparian filtration can effectively predict instream silt cover and embeddedness 
across a range of spatial scales in hopes of providing a simple and transferable decision-making tool to assist agencies with management prioritization in sedimentimpaired water systems. We focused on sections of the Roanoke, Dan, and Nottoway river systems (in Virginia and North Carolina, USA) based on impairment status and observations of the Roanoke logperch (Percina rex), a known sediment-sensitive species. More specifically, our study aimed to identify areas in the Roanoke, Dan, and Nottoway river basins with the highest percentages of silt cover and substrate embeddedness to prioritize areas for erosion control and riparian restoration. The broader purpose of our study aims to create a transferable framework that is simple and easily implemented by agencies to address sediment-impaired water systems. Where the most important components of a decision-support framework are analysis, design, construction, implementation, and monitoring (Sprague 1980), our study seeks to outline each of these elements for use by agencies engaged in managing water quality and species habitat. The structure of our framework integrates instream habitat surveys of silt cover and embeddedness (hindrances to benthic feeding by species such as the Roanoke logperch), geospatial analysis of watershed and local landscape characteristics, and statistical modeling. We used field habitat surveys of silt cover and substrate embeddedness as response variables to build a multiple linear regression (MLR) model with landscape characteristics as input variables that potentially predict instream sedimentation. While silt cover estimates are specific to silty-textured soils, embedded substrate could include a mix of clay, silt, and sand (Bain and Stevenson 1999). In this study we refer to the composite of fine embedded materials and silt cover collectively as "instream silt conditions" for convenience. In addition, we aimed to simplify geoprocessing steps to provide agencies with limited time and GIS resources a viable method for prioritizing field reconnaissance for management and restoration planning. Specific modeling objectives of our study included (1) determining which landscape characteristics explain more of the variance in instream silt conditions, (2) analyzing the influence of spatial scale on instream silt prediction accuracy and how this affects site prioritization, and (3) identifying the potential utility and limitations of using a statistical modeling approach for conservation agencies to prioritize riparian restoration.

\section{Methods}

\section{Study Area}

Our study comprised 76 12-digit hydrologic units (HUC-12s) in the upper Roanoke, Dan and Nottoway river basins in Virginia (Henley and Natural Resource Conservation Service and US Geological Survey 2006). The focal HUC-12s contain Roanoke logperch capture records provided by the Virginia Department of Game and Inland Fisheries (VDGIF), Virginia Tech, and other partners, as well as HUC-12s adjacent to Roanoke logperch capture records that reflect suitable potential logperch habitat (Fig. 1). We targeted Roanoke
Fig. 1 Study area map for the focal 76 HUC-12s located in the Roanoke, Dan, and Nottoway river basins in $\mathrm{NC}$ and VA. We chose HUC-12s based on Roanoke logperch capture records and potential habitat

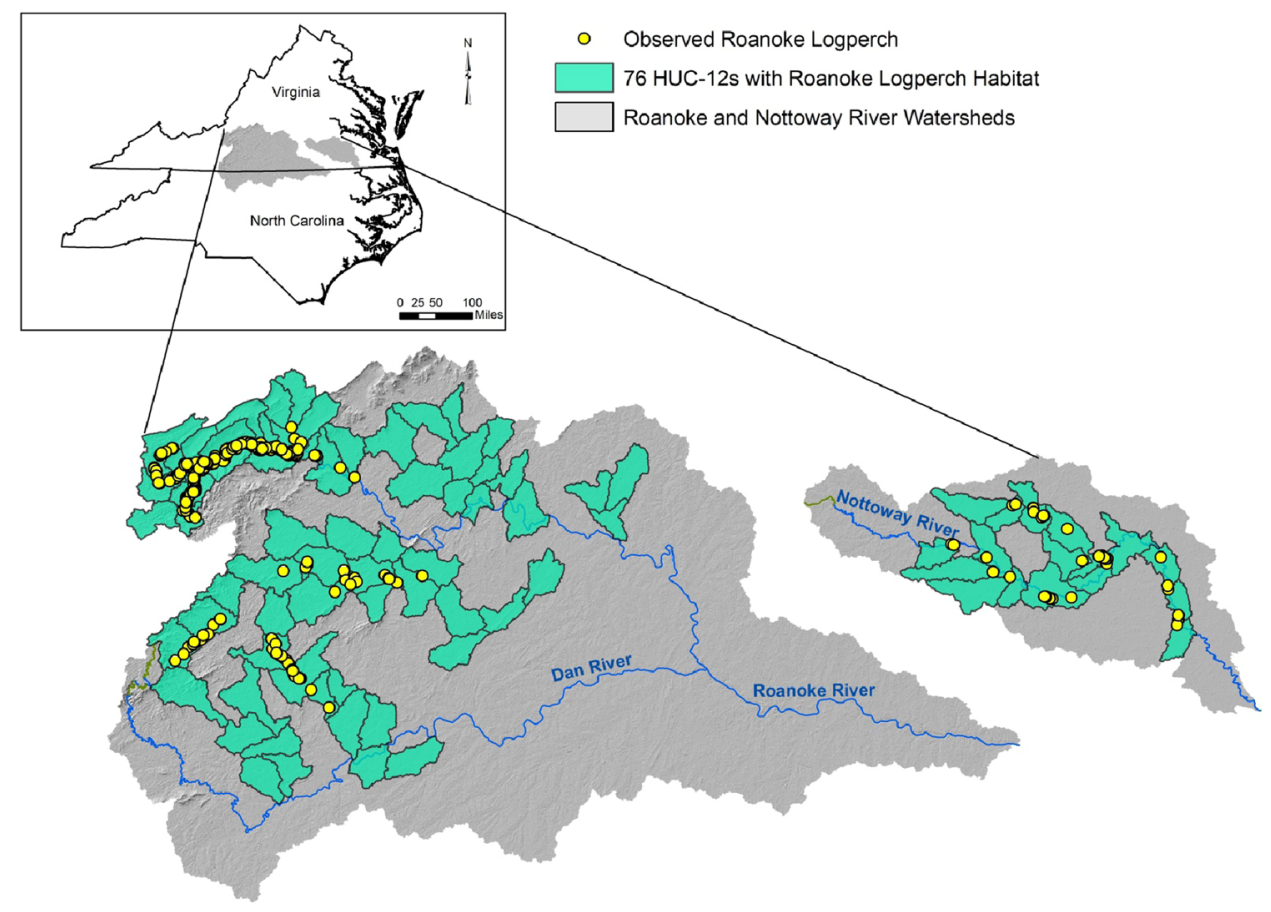


logperch habitat for this study because it is a federally endangered fish species impacted by silt cover and embeddedness of streambed substrate. Roanoke logperch overturn substrate with their snouts to feed on underlying organisms. Excess silt deposition into streams inhibits their ability to feed and reduces overall available food and habitat (Rosenberger and Angermeier 2003). Furthermore, the section of the Roanoke River from the confluence of Mason Creek (Roanoke County) to the Western Virginia Water Authority is listed on Virginia's 303d list for benthic species impairment due to excess sediment (The Louis Berger Group 2006).

\section{Initial Site Analysis}

Given the limited time and funding for this study, we were not able to assess stream reaches for all 76 HUC-12s. To select our focal sites in the Roanoke, Dan and Nottoway river systems, we conducted a GIS-based analysis to estimate soil loss and riparian filtration capacity for the 76 HUC-12s. In our GIS model, soil loss values estimate upland erosion rates that potentially contribute to levels of instream sediment (Renard et al. 1997), while riparian filtration capacity values attempt to capture sediment removal from overland flow by vegetative buffers (Chengfu et al. 2016). These estimates of riparian filtration could also partially explain a sediment delivery ratio (SDR) to streams that accounts for proportions of sediment yield from total upland erosion ( $\mathrm{Lu}$ et al. 2006). To incorporate soil loss and riparian filtration factors, we estimated 1) soil loss (SL) and 2) riparian filtration capacity (Rip Fil) to prioritize sites for further assessment.

Our GIS model to calculate soil loss was developed based on the Revised Universal Soil Loss Equation (RUSLE). This provided us with an initial estimate of upland sediment loading that influences instream conditions and potential habitat impairment. The full RUSLE calculates annual soil erosion (A) in tonnes per hectare per year with inputs of soil erosivity (R-factor), soil erodibility (Kfactor), length-slope calculations (LS-factor), cover management practices (C-factor) and the practice factor ( $\mathrm{P}$ factor; assumed to be 1) (Eq. 1; Lim et al. 2005; Jabar 2003).

$$
A=R K(L S) C P
$$

Interpretations of riparian filtration vary widely throughout the literature, from total forest cover within a watershed (Jones et al. 2001) to plot-scale measures of filtration rates (Mayer et al. 2007). We adopted the approach described in Villamagna et al. (2015) in which ecosystem services were assessed across protected lands in Virginia and North Carolina. The capacity of watersheds to filter out nutrients and sediment from overland flow was assessed based on the land cover/use within areas $0-50 \mathrm{~m}$ from surface waters. More specifically, this approach calculated the weighted average of pre-assigned land cover-based filtration values (Mayer et al. 2007) within the riparian areas where higher filtration weights were assigned to forests and grasslands compared to urban, agricultural, or highly human-altered landscapes. Land cover weights were initially adapted from a study focusing on nitrogen removal (Mayer et al. 2007). However, findings from Chengfu et al. (2016) suggest similar rates of sediment and nitrogen can be removed from overland flow by riparian vegetation. Although studies have shown that the width of vegetated riparian areas can affect sediment filtration rates (Castelle et al. 1993), we chose to use the National Land Cover Dataset (30 m resolution) to maintain a decision-making tool and framework that could easily be adopted by managing agencies. If a waterway's riparian area was classified as vegetated, it was assumed that the width of that vegetated buffer exceeded the recommended width of vegetated buffers to maximize sediment filtration. Equations and tables for data inputs and calculations are in the Appendix (Tables 1 and 2).

We used initial calculations of SL and Rip Fil at the HUC-12 level to guide field site selections. We placed each of the 76 HUC-12s into one of four categories: (1) High SL, Low Rip Fil, (2) High SL, High Rip Fil, (3) Low SL, Low Rip Fil, (4) Low SL, High Rip Fil. We determined category membership based on whether SL and Rip Fil values were above or below their calculated average value. We then ranked HUC-12s within each of the four categories and chose the top sites combined with site accessibility for a total of 30 field sites (Fig. 2). We chose sites from each of the four categories to capture a range of predicted site conditions for analysis. A complete list of field site locations is in the Appendix (Table 3).

\section{Field Assessment}

We considered silt cover and embeddedness as two important parameters to assess during field habitat surveys because Roanoke logperch feeding success is inhibited by substrate with excess fine sediment (Jastram et al. 2015). Our field assessment included transects within riffle and pool stream segments, and excluded runs. This is because riffles and pools represent the broadest range of sediment conditions, whereas runs are intermediate (Rosenberger and Angermeier 2003). At each site, we assessed a minimum of $100 \mathrm{~m}$ of geomorphic stream units characterized as pool and a minimum of $100 \mathrm{~m}$ characterized as riffle. We sampled stream sites until at least $100 \mathrm{~m}$ each of total pool and riffle was measured. Sites were 245-1410 m long.

To assess our focal parameters, percent silt cover and percent embedded, we used a multi-transect approach to record estimates of silt conditions at our 30 field sites. We 
Fig. 2 Green, yellow, orange, and red HUC-12s represent 30 chosen field sites and respective categories for each site. Each of the four categories was calculated as an initial assessment of expected soil loss (SL) and riparian filtration capacity (Rip Fil).

Representation from each category was chosen to sample a range of site conditions. Field sites were located proximally to HUC-12 pour points
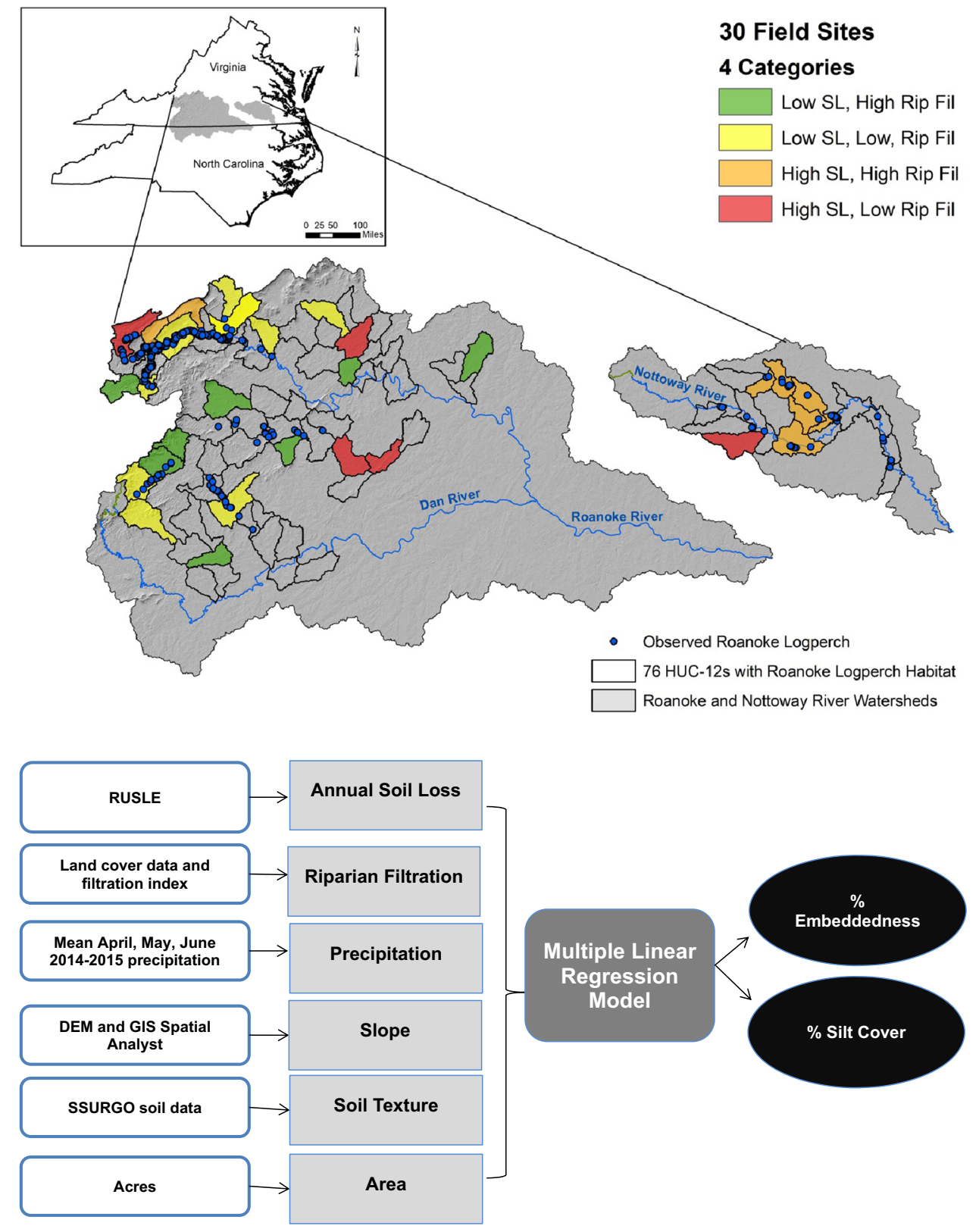

Fig. 3 Diagram of our multiple linear regression (MLR) model structure showing how each input variable was calculated or obtained from publicly available data. We used landscape characteristics as inputs for our MLR model to predict percent silt cover and embeddedness. We used this model structure to create a MLR model at three spatial scales sampled ten transects per site (five riffle and five pool). At each transect, we subdivided the stream width into fifths and recorded visual estimations of percent silt cover and percent embeddedness. Visual observations of silt were averaged per site to calculate mean percentages of silt cover and embeddedness. Visual silt estimations were deemed sufficient as they were used to develop a model intended to rank sites for prioritization instead of provide specific silt cover and embedded values.

\section{Statistical Analysis}

MLR modeling techniques are widely used as tools of prediction and broader application. Ecological models have used MLR explanatory power to accurately predict hydrologic flows and sediment transport (Seelbach et al. 2011; Abrahart and White 2001). However, MLR modeling has not been widely applied to prioritize or analyze restoration sites. Our study uses a MLR modeling approach to provide a model that can be applied beyond the scope of our analysis for site prioritization in other stream systems.

To construct MLR models, we initially used six landscape characteristics as predictor variables for instream percent silt cover and percent embeddedness (Fig. 3). We chose predictive variables based on landscape characteristics with relationships to soil transport, including predicted annual soil loss, riparian filtration capacity, mean spring precipitation, mean watershed percent slope, percent silty- 
textured soils ( $>70 \%$ silt), and watershed area (Brady and Weil 2008). We used stepwise parameter selection techniques to optimize and reduce model inputs. We chose final model input (i.e., predictor) variables based on the lowest Akaike information criterion (AIC) among available models, calculated using $\mathrm{R}$ statistical packages. To assess landscape characteristics' explanatory power we compared parameter $p$-values $(p<0.05$ is significant) for our six predictors.

Collinearity, or the correlation between multiple model input variables, potentially affects MLR model effectiveness. High collinearity can skew model results (Hair et al. 1995). We quantified collinearity of our MLR model parameters by calculating a variance inflation factor (VIF) for each input variable. For VIF assessment we used the following values suggested by Hair et al. (1995): VIF $>1$ is not highly correlated, VIF $=1-10$ is moderately correlated, and VIF $>10$ is highly correlated.

\section{Soil Loss}

Greater amounts of predicted upland soil erosion, calculated using RUSLE, is a potential indicator of increased silt deposition into waterways. Therefore, we expect soil loss estimates from RUSLE to positively relate to instream silt cover and embeddedness. An advantage of using RUSLE is that it can be calculated in ArcMap at any spatial scale, ranging from a small reach to a full watershed. This is appealing from a management perspective, where optimal analytical resolution may vary by project. However, the RUSLE does not account for sediment delivery to streams and instream transport and deposition dynamics (Lim et al. 2005; Brady and Weil 2008).

\section{Riparian Filtration}

We used riparian filtration capacity as a potential negative correlate with instream silt conditions. Since riparian vegetation protects stream banks and traps a portion of sediment in overland flow before entering waterways, we expect riparian filtration capacity to inversely relate to instream silt cover and embeddedness. As mentioned in the initial site analysis, we calculated riparian filtration capacity as a function of land cover, where forests and grasslands have the highest expected sediment filtration rates.

\section{Precipitation}

We quantified the potential influence of precipitation on soil loss by calculating mean spring (April, May, and June) precipitation per site. Greater amounts and intensity of precipitation are expected to increase sediment loading and eventual silt cover and embeddedness of stream substrates.
To maintain a relatively straightforward and transferable approach we used monthly data instead of daily precipitation data to simplify GIS processing and model creation. We collected pre-processed monthly data from PRISM datasets to provide extrapolated precipitation values in grid cell format across each watershed. We averaged monthly PRISM grid cells (PRISM Climate Group, Oregon State University 2014-2015) to calculate mean spring precipitation per site.

\section{Slope}

Slope is another positive driver of soil erosion and transport. Surface water runoff transports downslope and later deposits sediment in flat or lowland areas, such as wetlands and streams (Smith and Pun 2010). We calculated mean upland slope in ArcMap using a $30 \mathrm{~m}$ digital elevation model (DEM) (USDA NRCS 2010).

\section{Soil Texture}

Soil texture is an important factor explaining erosion potential. Silty-textured soils are the easiest to dislodge and transport (Schaetzl and Anderson 2005). Furthermore, silt was commonly observed coating streambed substrate and impacting habitat and water quality during field habitat surveys. We included Soil Survey Geographic Database (SSURGO) soil texture data as a factor in MLR model construction, (Soil Survey Staff et al. accessed 2015-2016) and calculated the areal percentage of silty-textured soils $(>70 \%$ silt) in each watershed. We focused on silty-textured soils as a MLR model input to determine whether the presence of upland erodible soils in a watershed relates to levels of instream silt conditions.

\section{Spatial Scale}

Instream sediment loads potentially originate from various locations in a watershed. Sediment contributions may be local or remote (Trabucchi et al. 2013). To consider multiple sources of sediment load we calculated our statistical model inputs at three scales, in order of decreasing extent: (1) watershed, (2) HUC-12, and (3) field survey reach. Watershed areas ranged from 6000 to 300,000 acres. To delineate watershed boundaries, we used a $30 \mathrm{~m}$ DEM (USDA NRCS 2010) and the spatial analyst toolset in ArcMap. Watershed pour points were defined as the downstream-most survey locations. Field sites were located as close to HUC-12 pour points as possible, given accessibility. The HUC-12 scale is a 6th-level watershed, or subwatershed unit, that captures local tributaries, and is the quickest spatial unit to assess. No delineations are needed, as the HUC-12 boundaries are available for download from 
USGS (Henley and Natural Resource Conservation Service and US Geological Survey 2006). Our observed HUC-12 units ranged from 10,000 to 40,000 acres in size. Stream reach-scale catchments ranged from 17 to 8000 acres. To delineate reach-scale catchments, we first delineated watersheds based on the starting and ending points of field survey reaches. We then subtracted the upstream drainage area from the total to yield the reach-scale catchment area.

Due to the range in extent of our three focal spatial scales and the different erosion and sediment transport mechanisms at play, we expected MLR model results to vary by scale. Watershed model outputs represent full drainage area contributions to sediment loading. Reach-scale estimates represent local contributions to sediment loading, and HUC12 estimates represent intermediate-scale sediment loading. We expected reach-scale sediment contributions to most strongly affect instream silt conditions at sites and watershed-scale contributions to have the weakest effects.

\section{Silt and Restoration Ranking}

We used ranking to prioritize sites for riparian restoration. To assess statistical model effects on ranking we ranked sites based on two criteria: (1) silt cover and embeddedness and (2) potential riparian restoration responsiveness. To assess statistical model performance and spatial scale impacts on site rank, we compared observed rankings to MLR model predicted rankings. Initially, we ranked each of the 30 sites based on observed percent silt cover and embeddedness values. We then used MLR equations that predicted the greatest observed variability in silt for our three spatial scale models to calculate predicted percent silt cover and percent embeddedness. We ranked each of the 30 sites based on model-estimated silt values. To quantify ranking differences, we calculated mean rank difference and the number of under-prioritized sites out of 30. Mean rank difference captures how much predicted rankings varied from observed rankings, while under-prioritized sites are those where the model predicted less silt cover and embeddedness than we observed. We considered underprioritization of the most impaired sites to be a concern, so we also included the number of under-ranked sites in our analysis to represent under-prioritization.

To prioritize sites for restoration, we used a riparian scenario analysis to evaluate sites based on potential restoration effectiveness. Using the linear equations that explained the greatest observed variability in silt cover and embeddedness (i.e., best fit models), we assessed changes in predicted silt with a $25 \%$ increase in riparian filtration capacity. These capacity increases could be achieved by tree planting or root revetment (Perry et al. 2015). Sites were ranked again by potential reductions in silt. Ranking sites by potential restoration effectiveness provides an alternative riparian restoration prioritization technique.

\section{Results}

\section{Statistical Analysis}

\section{Landscape characteristics}

Our MLR models explained significant proportions of variance in silt cover $(0.16-0.33)$ and embeddedness (0.23-0.46) at all three spatial scales (Table 1). MLR model equations predicted more of the variance in percent embeddedness compared to silt cover. However, most of the variance in percent embeddedness and silt cover was not explained by model results. All model inputs for each of the three spatial scales were not correlated (VIF $<1$ ) or moderately correlated $(1<\mathrm{VIF}>10)$. Collinearity was not a concern so we kept all optimal inputs in our statistical model results.

Riparian filtration explained a significant portion of observed variation in percent silt cover among study sites at all three spatial scales $(p<0.05)$, and was the most predictive variable overall for percent silt cover. However, riparian filtration was only included in the watershed-scale model for percent embeddedness. As expected, riparian filtration capacity was inversely related to silt cover and embeddedness.

Mean precipitation was statistically significant $(p<0.05)$ for percent embeddedness models at all three spatial scales, and was the most predictive variable overall for embeddedness. However, the only percent silt cover model that included mean precipitation as a predictor was for the reach scale. Bivariate relationships were positive between mean spring precipitation and percent embeddedness and percent silt cover.

Annual soil loss was statistically significant in HUC-12 and reach-scale embeddedness models $(p=0.006$ for both models), and was included in the reach-scale percent silt cover model, but was not statistically significant $(p=0.09)$. In contrast to expectations, upland soil loss was inversely related to percent instream silt cover and percent embeddedness.

Soil texture, slope, and catchment area were also included in some models for silt cover and embeddedness, but were not statistically significant ( $p$-values of 0.07 and 0.19 , respectively). Percent silty-textured soil was included in watershed and reach-scale models for embeddedness and was inversely related to embeddedness. Slope was positively related to embeddedness at the watershed scale ( $p=$ 0.12). Catchment area was included in HUC-12 percent silt cover and reach-scale percent embeddedness models, but 


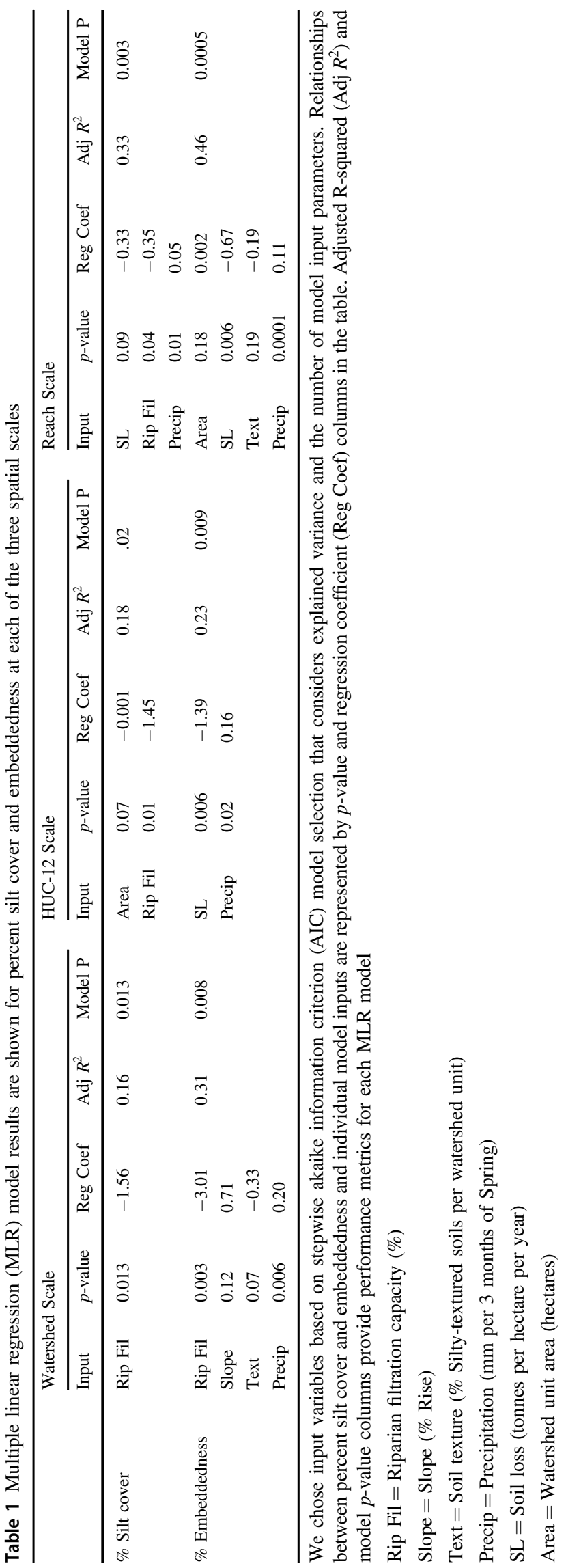

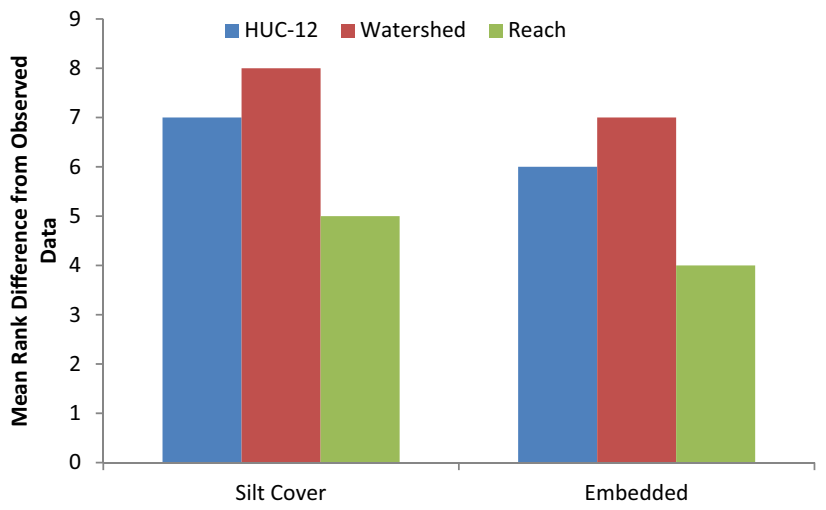

Fig. 4 Mean rank difference between statistical model results and observed benthic condition. Reach-scale models have a lower rank difference for percent silt cover and embeddedness models, suggesting greater accuracy relative to HUC-12 and watershed scale models

were not statistically significant ( $p$-values of 0.07 and 0.18 respectively; Table 1).

\section{Spatial scale}

Reach scale models explained more of the observed variability of instream silt cover (Adj. $R^{2}=0.33$ ) and embeddedness (Adj. $R^{2}=0.46$ ) with greater statistical significance than HUC-12 or watershed scale models. HUC-12 and watershed scale models predicted instream conditions with similar statistical performance. For percent silt cover, the HUC-12 scale model was a better predictor than the watershed scale model. For percent embeddedness, the watershed scale model was a better predictor than the HUC12 scale model (Table 1).

\section{Silt and Restoration Ranking}

We ranked each site based on observed and predicted percent silt cover and embeddedness. Reach scale predictions more accurately ranked the 30 field sites based on the mean difference in ranks assigned based on modeled versus field observations of silt (Fig. 4). Under-prioritization is an issue for ranking sites, as degraded sites are often the most in need of restoration. Sites were highly under-prioritized across all three spatial scales. This suggests that our modelpredicted percent silt cover and embeddedness values are lower than observed conditions. The reach scale model for percent silt cover performed slightly better than models for the other two scales. The reach scale model underprioritized 10 out of 30 sites, while the HUC-12 model under-prioritized 12 sites, and the watershed model underprioritized 14 sites. For the percent embedded model, all three spatial scales performed equally poorly. Around half of the sites were under-prioritized, with both the reach and 


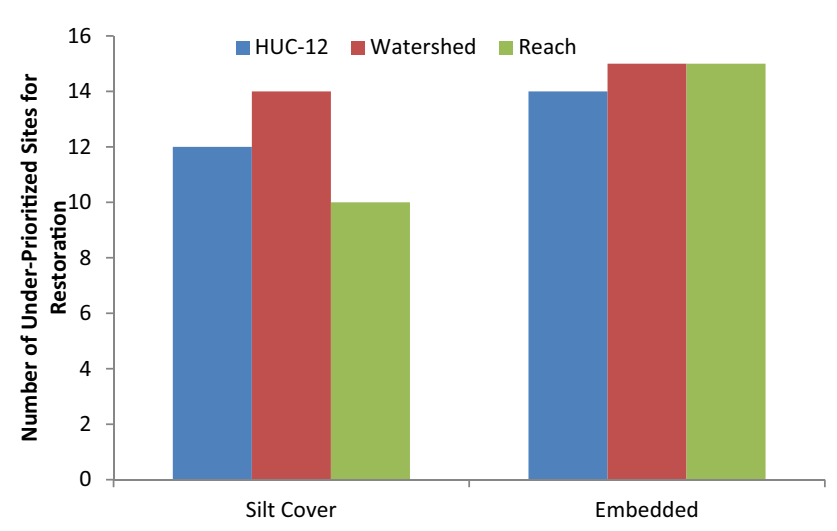

Fig. 5 Under-ranking of predicted versus observed benthic conditions. Fewer sites were under-prioritized by the percent silt cover model at the reach scale than at other scales. All sites performed similarly for the percent embeddedness model

HUC-12 models under-prioritizing 14 sites, and the watershed scale model under-prioritizing 15 sites (Fig. 5).

Riparian filtration was a significant predictor in all percent silt cover models, but only at the HUC-12 scale in the percent embeddedness model. In order to compare riparian restoration scenario results across all three spatial scales, we only considered models of percent silt cover. Our riparian scenario analysis yielded values for potential reductions in percent silt cover with a $25 \%$ increase in riparian filtration capacity. Site restoration rankings varied when ranked based on potential reduction in percent silt cover and current percent silt cover (Fig. 6). For all three spatial scales, the greatest potential silt reductions attributed to increased riparian filtration occurred in sections of the Nottoway River basin. The most degraded sites, with the highest percent silt cover and estimated to be the least affected by increased filtration capacity, are located in upper Roanoke River basin, near the City of Roanoke.

\section{Discussion}

\section{Effects of Landscape Characteristics on Instream Silt}

While our statistical model results provide insight into the influences of landscape characteristics on instream silt dynamics and the complexity of those relationships, improvements in geospatial data resolution and/or more representative input parameters for sediment transport are needed to strengthen model results and their applicability elsewhere. For example, riparian filtration capacity explained significant proportions of observed variance in percent silt cover, modeled at all three spatial scales, but was less useful in explaining percent embeddedness. This pattern suggests that (a) silt cover and embeddedness are regulated by distinctive processes and (b) riparian filtration may play a greater role in regulating silt cover.

Higher riparian filtration capacity, associated with forest cover and grasslands, increases sediment retention and reduces sediment loading into streams (Perry et al. 2015). Our MLR model results support this mechanism with a predicted inverse relationship between riparian filtration capacity and percent silt cover. Sutherland et al. (2002) similarly found higher bed load and suspended sediment transport rates in areas with less vegetation. Riparian cover is potentially a good indicator of stream bed conditions in addition to total sediment entering streams. Our findings are useful for management, as riparian condition can be managed to improve bank stability and reduce instream silt (VADCR 2004). However, riparian filtration capacity did not significantly explain instream embeddedness. This may in part be explained by instream transport mechanisms that were not the focus of this study. In such, particles causing embeddedness may have been introduced to the system during a time when riparian cover is less effective (e.g., winter) or absent, the latter being an example of legacy sediment (James 2013). Alternatively, sediment contributing to embeddedness may originate from bank erosion, which is not regulated by riparian filtration (Hooke 1979).

Mean spring precipitation was a significant predictor of percent embeddedness at all three spatial scales we modeled, but only at the reach scale for predicted percent silt cover. This pattern reinforces the notion that silt cover and embeddedness are regulated by distinctive processes. Several mechanisms potentially explain this result. Precipitation is a major driver of soil erosion, and more sediment transport into streams is expected during intense storms (Underwood et al. 2015). Our modeled relationship between spring precipitation and embeddedness potentially represents precipitation-driven high sediment loads and subsequent streambed deposition, manifesting as embeddedness. However, instream sediment flushing is also expected to increase during high flow events as portions of bedload sediment are re-suspended in the water column and transported downstream (Milhous 1998). We expect sediments measured in our assessments of silt cover to be more readily flushed than those measured in our assessments of embeddedness, as filled streambed interstices are more protected from flushing during high flow events by surrounding gravel (Levasseur et al. 2006; Beschta and Jackson 1979). Instream flushing mechanisms (e.g., frequency, magnitude, and duration of storms) were not explicitly included in our models, but may help explain observed variability. However, at the reach scale, greater proportions of estimated soil loss could have reached streams depending on local SDRs, where not all portions of instream sediment were flushed during storms (Van Rompaey et al. 2001). To improve precipitation contributions to explaining instream 


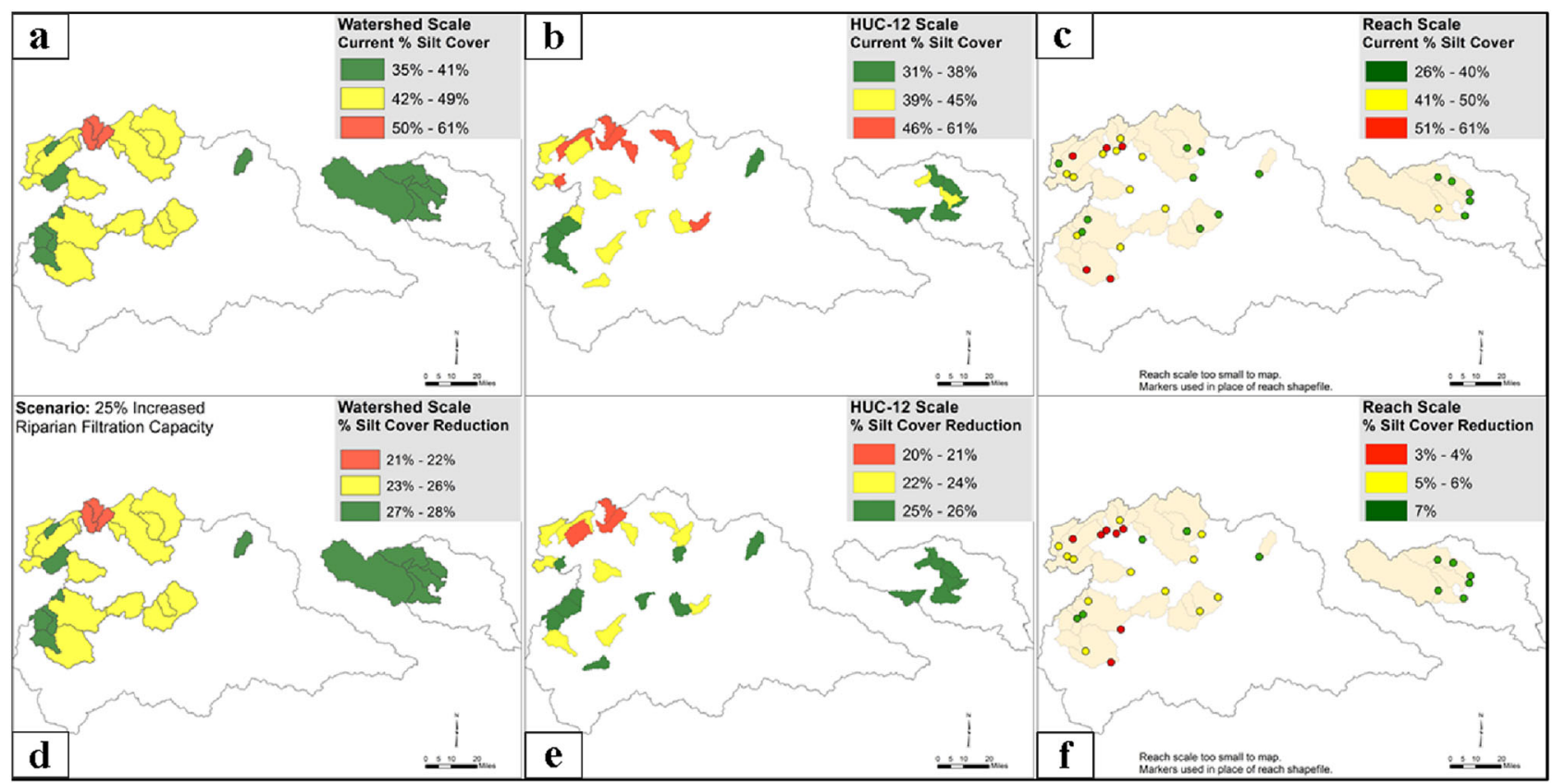

Fig. 6 a-f Images a-c show current percent silt cover at each of the three spatial scales. We calculated percent silt cover using linear equations that predicted the greatest observed variability in instream silt conditions. In images $\mathbf{d}-\mathbf{f}$ we used the same equations to include riparian filtration increased by $25 \%$. To assess changes in silt, we calculated the estimated percent reduction in silt cover with increased riparian filtration capacity silt cover and embeddedness, storm metrics could be incorporated into regression models. For example, storm frequency, magnitude, and/or duration could be included as potential predictors, given that soil loss increases with storm intensity (Mohamadi and Kavian 2015).

Although upland soil loss explained significant proportions of observed variance in percent embeddedness at the two smaller spatial scales and silt cover at the reach scale, negative bivariate relationships were contrary to expectations. Unexpected negative relationships between soil loss and silt cover and embeddedness can potentially be explained by examining regional patterns. RUSLE calculations estimated the highest annual soil values in the Nottoway River basin compared to the Roanoke River basin (see Table 5 in the Appendix) with high values largely driven by the presence of agricultural land cover (Homer et al. 2015). However, visual estimates of silt cover and embeddedness at field sites in the Nottoway River basin were near the calculated average of all field observations. Counter-intuitive model results that suggest a negative relationship between soil loss and silt cover and embeddedness were likely driven by overestimated RUSLE soil loss values. RUSLE estimates could be improved by increasing individual RULSE variable raster resolution from $30 \mathrm{~m}$ to $10 \mathrm{~m}$ to capture more variability in landscape factors and potentially by updating the rainfall erosivity $(\mathrm{R})$ factor to better reflect current climatic conditions in these regions. Furthermore, estimates of upland soil loss that is delivered into streams could be enhanced by including a SDR that estimates actual portions of eroded soil reaching streams (Borselli et al. 2008). SDR values could be particularly useful for sections of the Nottoway River basin, where soil loss estimates are high due to agriculture, but slope is less steep, meaning less sediment is likely carried into waterways (Renard et al. 1997; USDA NRCS 2010).

Mean slope, watershed area, and percent silty-textured soils were never top predictors and were included only occasionally in silt models. While these variables play a role in sediment transport (Brady and Weil 2008), they do not significantly influence instream silt dynamics according to our model results. Silty-textured soils were unexpectedly negatively related to embeddedness. A negative relationship between texture and embeddedness could potentially be explained by larger, sandy particle sizes (up to $2 \mathrm{~mm}$ ) embedding streambed substrate (Bain and Stevenson 1999).

While some predictor variables in our MLR model explained significant proportions of instream silt cover and embeddedness, the majority of variance in instream conditions was not explained by MLR models. Model explanatory power could be enhanced by adding input variables, such as channel slope, that reflects instream sediment transport (Montgomery and Buffington 1997). Including a model input variable that incorporates instream transportation dynamics could especially improve predictions of silt 
cover in situations where silt cover is less protected from flushing during storms than embedded material (Beschta and Jackson 1979).

\section{Utility of Modeling at Selected Spatial Scales}

Models focused on the stream reach scale more accurately predicted patterns of instream silt cover and embeddedness than watershed scale models. The reach scale also ranked sites more accurately compared to observed instream conditions. Greater modeling accuracy at the reach scale may reflect less variability (and more precision) in predictors. Using mean precipitation as an example, the mean of only two PRISM grid cells across the extent of a reach contains less variability than averaging ten $30 \mathrm{~m}$ grid cells at the watershed scale. The same concept is applicable to other predictor variables. However, reach scale analyses are limited to only including local contributions of sediment loading. Upland areas and instream processes that extend beyond stream reach lengths are not considered in reach scale calculations. Alternatively, variables not included in our models may be more influential at larger spatial extents, leading to less variance explained by our models.

HUC-12 and watershed scale models explained similar proportions of observed variability in benthic conditions, and ranked sites similarly, though the latter were slightly less accurate in most cases. Larger-scale modeling is potentially less accurate due to increased variability in parameter calculations. Greater modeling assumptions are required to generalize landscape characteristics of precipitation, soil texture, slope, riparian filtration, and soil loss across the entire extent of a watershed versus a much smaller stream reach. However, watershed scale calculations can consider all contributions of soil loss drivers to instream silt conditions, which may also lead to overestimations of sediment loading and instream silt conditions (Chengfu et al. 2016). Integrating SDRs into soil loss estimates to calculate fractions of eroded sediment that are deposited into streams (Lee and Lee 2010) may improve watershed and HUC-12 scale modeling results.

While model results suggest the reach scale more accurately predicts instream silt conditions and ranks sites based on predicted percent silt cover, tradeoffs exist between implementing management actions in smaller versus larger spatial units. Reach scale analyses are appealing in many situations where small-scale riparian restoration efforts are desired. In this project, stream reaches ranged from 245 to $1410 \mathrm{~m}$ in length. In many cases, BMPs are implemented on individual land parcels, or smaller scales (VADCR 2017; VADOF 2011) Unless parcels extend beyond the reach scale, or are connected to other BMP areas, reach scale analyses most appropriately assess these areas and can provide a method of prioritizing BMP areas, or can be used to estimate potential riparian restoration effectiveness in these areas.

Although our models suggest that the watershed scale is less effective for predicting instream silt and ranking sites, watershed scale modeling may be more desirable. While many projects are only funded for partial or reach scale restoration efforts (VADCR 2004), large, watershed scale restoration is potentially much more impactful for ecosystem health and community benefits, with the potential of getting more "bang for the buck". The cost/benefit analysis of Holmes et al. (2004) suggests a nonlinear relationship exists between riparian restoration length and beneficial outcomes. The suggested positive exponential relationship between restoration length and societal and ecological benefits advocates for conducting larger scale restoration efforts where possible. According to Holmes et al. (2004), riparian buffer connectivity along streams is highly valuable: a long continuous buffer zone is potentially more effective than a series of disjunct buffer zones that collectively sum to the same fluvial length as there are fewer locations that are vulnerable to unimpeded runoff.

\section{Silt and Restoration Ranking}

From a management standpoint, ranking is important because it informs prioritization. Ranking results also provide insight as to whether spatial scale and model accuracy affect site ranking and prioritization. We ranked each of our 30 focal sites by current percent silt and embeddedness to prioritize the most degraded sites. As expected, rankings varied by spatial scale. Reach scale silt predictions ranked sites more accurately than HUC-12 or watershed scale rankings when compared to observed silt rankings. This corroborates the finding that the reach scale statistical model explained more observed variance of instream conditions than HUC-12 and watershed scale models.

Our results suggest that local sediment contributions, modeled by reach scale analyses, more accurately represent instream silt conditions than those modelled at the HUC-12 and watershed scales. Our results also suggest statistical model accuracy affects ranking accuracy. This has implications for watershed scale modeling used to prioritize sites. When using a statistical approach, watershed scale models are potentially less accurate than smaller, reach scale models for predicting instream silt conditions and ranking sites. Therefore, watershed scale models are potentially less effective for restoration site prioritization. Our results are consistent with findings from Chengfu et al. (2016), that sediment dynamics are better predicted at smaller spatial scales.

VADCR's stream restoration manual explicitly states that the most degraded sites are not always prioritized because they are often more expensive to restore and the expense may outweigh the utility in those extreme cases. As an alternative 
to prioritizing sites by degradation status, we also assessed sites by potential restoration effectiveness. We hypothetically increased riparian filtration values to estimate reductions in silt with increased filtration capacity. While this approach is useful, it stipulates that riparian filtration provides explanatory power in statistical models. It is therefore not always applicable, and for this study, we were only able to assess riparian scenarios for percent silt cover models.

As expected, riparian scenario results ranked sites by reductions in silt differently than ranking by current percentages of silt. Rankings also differed by spatial scale. However, scenario analysis results from all three spatial scales show that the greatest potential reductions in silt cover occur in sites along the Nottoway River. This is potentially due to extensive farming and less forest cover in the Piedmont region of Virginia, where there is a greater need for vegetative stream buffers (Homer et al. 2015).

According to model results, the most degraded sites, and sites estimated to be the least impacted by riparian restoration, are located in the City of Roanoke. This potentially provides an example of where site restoration needs may extend beyond riparian revegetation utility. Other sections of the upper Roanoke River are also degraded, with less potential restoration effectiveness than in the Nottoway River basin. This may be because sections of the upper Roanoke River basin are already heavily forested, and an increase in vegetative cover may have less of an impact than in agricultural areas (Holmes et al. 2004; Homer et al. 2015). In these forested areas, more research is needed to better understand the spatial and temporal source of sediment loading and instream transport. Specific research questions could address how effectively current riparian buffers are filtering sediment, and estimate bank erosion contributions to instream silt levels.

Riparian revegetation scenarios can assist decisionmaking for resource management. Estimated restoration effectiveness provides an important perspective on prioritizing sites for riparian restoration, but also for understanding varying restoration needs within a sub-basin. This understanding of restoration need is especially important in areas where degradation status does necessarily not drive site prioritization.

\section{Conclusions}

Landscape characteristics with known relationships to sediment loading reflect different stages within sediment transport processes. Although riparian filtration and precipitation are some of the processes most strongly influencing sediment loading, our results suggest that they may not be equally representative of instream silt conditions, like silt cover and embeddedness. Riparian filtration explained the greatest variance in instream silt cover, while spring precipitation best explained embeddedness.

The proper spatial scale of analysis is another issue to tackle when assessing models for riparian restoration prioritization. Our results have shown that smaller, reach scale modeling approaches are more accurate than larger, watershed scale approaches. This modeling accuracy also affects ranking, and suggests caution may be needed when assessing larger spatial units.

Ecological models are useful for improving site assessment efficiency, but are still in need of improvement. MLR models in particular, are good management tools because once they have been constructed, model results can be applied to other watersheds with similar characteristics, greatly increasing site modeling efficiency over time. For example, specific equations derived in this study could be used in physiographic regions similar to our focal basins.

Drawbacks to using MLR approaches in management include tradeoffs between simplicity and accuracy. Our study created a simplistic statistical model that could be quickly implemented by resource managers. However, modeling accuracy was likely reduced by only capturing parts of landscape sediment transportation processes. Our results for landscape metrics could serve as proxies for use by resource managers with potential improvements to current model inputs, or by including additional sediment contributing factors. Potential improvements may include increasing the resolution of current data inputs, combining soil loss estimates with a SDR, or calculating storm intensity to enhance precipitation contributions to instream silt. Additional parameters that may inform instream sediment dynamics and channel erosion could include channel slope, or in the case of soil loss, using a sediment loading model, such as the Soil and Water Assessment Tool (SWAT) in place of the empirical RUSLE model used in this study. SWAT incorporates additional hydrologic factors (e.g., runoff vs. infiltration) that account for upland and instream sediment transport dynamics with a temporal component (Zhang et al. 2011).

In addition, scenario analysis enhances the utility of MLR model equations and provides a powerful tool to resource managers. Riparian scenarios estimate potential revegetation effectiveness, allowing for more informed resource management decision-making. Restoration scenarios also facilitate a better understanding of watershed system response to various levels of rehabilitation.

The models produced in this study provide a first step toward integrating statistical modeling into restoration prioritization strategies and offer great promise to enhancing habitat for sediment-sensitive species, like the Roanoke logperch. This analytical approach can potentially be used as a building block for future prioritization efforts with the objective of restoring benthic habitats impacted by fine sediment. 
Acknowledgements This project was supported by the Center for the Environment at Plymouth State University and the VDGIF. We thank Zachary Martin from the Department of Fish and Wildlife Conservation at Virginia Tech for largely developing field methodology and surveying stream sites. We also thank undergraduate students that participated in field data collection. We thank Mark Green and two anonymous reviewers for helpful comments on the manuscript. The Virginia Cooperative Fish and Wildlife Research Unit is jointly sponsored by the U.S. Geological Survey, Virginia Polytechnic Institute and State University, VDGIF, and Wildlife Management Institute. Use of trade, firm, or product names does not imply endorsement by the U.S. Government.

\section{Compliance with ethical standards}

Conflict of interest The authors associated with this manuscript certify that they have no affiliations with any entity with financial or nonfinancial interests in the topics discussed herein.

\section{Appendix}

Tables 2-7.

Table 2 Riparian filtration capacity index adapted from Mayer et al. 2007

\begin{tabular}{lll}
\hline Land cover code & Description & Filtration capacity $(\%)$ \\
\hline 11 & Open water & 0 \\
21 & Developed, open space & 48.6 \\
22 & Developed, low intensity & 35.1 \\
23 & Developed, medium intensity & 18.9 \\
24 & Developed, high intensity & 5.4 \\
31 & Barren land (rock/sand/clay) & 0 \\
41 & Deciduous forest & 72.2 \\
42 & Evergreen forest & 72.2 \\
43 & Mixed forest & 72.2 \\
52 & Shrub/scrub & 54 \\
72 & Sedge/herbaceous & 54 \\
81 & Pasture/hay & 54 \\
82 & Cultivated crops & \\
90 & Woody wetlands & \\
95 & Emergent herbaceous wetlands & \\
\end{tabular}

We joined filtration capacity percentages to National Land Cover Dataset (NLCD) 2011 datasets to calculate mean riparian filtration capacity per site. Filtration capacity represents the percent of estimated sediment removed from overland flow.

Table 3 Soil loss (SL) and riparian filtration capacity (Rip Fil) calculations for all 76 HUC-12s are shown in the table below

\begin{tabular}{|c|c|c|c|}
\hline HUC-12 & Soil loss (tonne hec ${ }^{-1} \mathrm{yr}^{-1}$ ) & Rip fil capacity (\%) & Category \\
\hline 030101010103 & 1.210518525 & 67.1 & Low SL, High Rip Fil \\
\hline 030101010104 & 4.797240082 & 65.5 & High SL, Low Rip Fil \\
\hline 030101010105 & 2.622790139 & 63.8 & High SL, Low Rip Fil \\
\hline 030101010201 & 4.595486995 & 64.1 & High SL, Low Rip Fil \\
\hline 030101010202 & 2.308952002 & 63.8 & High SL, Low Rip Fil \\
\hline 030101010203 & 2.039947886 & 65.1 & Low SL, Low Rip Fil \\
\hline 030101010301 & 1.255352545 & 58.0 & Low SL, Low Rip Fil \\
\hline 030101010302 & 1.098433477 & 63.8 & Low SL, Low Rip Fil \\
\hline 030101010401 & 2.577956119 & 54.6 & Low SL, Low Rip Fil \\
\hline 030101010402 & 0.694927302 & 63.1 & Low SL, Low Rip Fil \\
\hline 030101010403 & 1.883028817 & 54.2 & Low SL, Low Rip Fil \\
\hline 030101010404 & 0.85184637 & 46.4 & Low SL, Low Rip Fil \\
\hline 030101010503 & 3.31771744 & 63.9 & High SL, Low Rip Fil \\
\hline 030101010601 & 3.003879304 & 66.3 & High SL, High Rip Fil \\
\hline 030101010603 & 3.228049401 & 60.7 & High SL, Low Rip Fil \\
\hline 030101010701 & 1.501939652 & 64.1 & Low SL, Low Rip Fil \\
\hline 030101010702 & 1.120850487 & 62.5 & Low SL, Low Rip Fil \\
\hline 030101010801 & 2.846960236 & 65.6 & High SL, Low Rip Fil \\
\hline 030101010802 & 3.071130333 & 65.3 & High SL, Low Rip Fil \\
\hline 030101010803 & 2.196866954 & 67.8 & Low SL, High Rip Fil \\
\hline 030101010804 & 4.304065868 & 67.9 & High SL, High Rip Fil \\
\hline 030101010903 & 3.474636508 & 68.5 & High SL, High Rip Fil \\
\hline
\end{tabular}


Table 3 (continued)

\begin{tabular}{|c|c|c|c|}
\hline HUC-12 & Soil loss (tonne hec ${ }^{-1} \mathrm{yr}^{-1}$ ) & Rip fil capacity (\%) & Category \\
\hline 030101011001 & 3.878142683 & 67.5 & High SL, High Rip Fil \\
\hline 030101011002 & 2.757292197 & 67.3 & High SL, High Rip Fil \\
\hline 030101011103 & 2.421037051 & 65.4 & High SL, Low Rip Fil \\
\hline 030101011201 & 3.497053518 & 67.5 & High SL, High Rip Fil \\
\hline 030101011203 & 2.331369012 & 69.1 & Low SL, High Rip Fil \\
\hline 030101011303 & 3.541887537 & 62.0 & Low SL, Low Rip Fil \\
\hline 030101011404 & 2.46587107 & 65.6 & High SL, Low Rip Fil \\
\hline 030101011406 & 3.093547343 & 62.3 & High SL, Low Rip Fil \\
\hline 030101011501 & 6.254345715 & 66.1 & High SL, High Rip Fil \\
\hline 030101011502 & 2.936628275 & 63.3 & High SL, Low Rip Fil \\
\hline 030101011503 & 3.160798372 & 64.3 & High SL, Low Rip Fil \\
\hline 030101011505 & 3.922976703 & 66.1 & High SL, High Rip Fil \\
\hline 030101020101 & 5.559418413 & 64.4 & High SL, Low Rip Fil \\
\hline 030101020205 & 5.80600552 & 68.2 & High SL, High Rip Fil \\
\hline 030101020206 & 3.922976703 & 68.6 & High SL, High Rip Fil \\
\hline 030101020207 & 4.326482878 & 68.8 & High SL, High Rip Fil \\
\hline 030101030305 & 1.726109749 & 67.5 & Low SL, High Rip Fil \\
\hline 030101030401 & 1.389854603 & 64.5 & Low SL, Low Rip Fil \\
\hline 030101030404 & 2.443454061 & 67.8 & High SL, High Rip Fil \\
\hline 030101030407 & 2.869377246 & 66.3 & High SL, High Rip Fil \\
\hline 030101030408 & 1.300186564 & 68.8 & Low SL, High Rip Fil \\
\hline 030101030409 & 1.210518525 & 63.2 & Low SL, Low Rip Fil \\
\hline 030101030601 & 1.457105633 & 67.5 & Low SL, High Rip Fil \\
\hline 030101030603 & 1.232935535 & 69.5 & Low SL, High Rip Fil \\
\hline 030101030604 & 1.345020584 & 68.0 & Low SL, High Rip Fil \\
\hline 030101030701 & 1.412271613 & 67.9 & Low SL, High Rip Fil \\
\hline 030101030702 & 1.300186564 & 64.0 & Low SL, Low Rip Fil \\
\hline 030101030801 & 1.68127573 & 60.5 & Low SL, Low Rip Fil \\
\hline 030101030803 & 1.860611808 & 58.4 & Low SL, Low Rip Fil \\
\hline 030101030806 & 1.457105633 & 66.9 & Low SL, High Rip Fil \\
\hline 030101030807 & 1.726109749 & 64.5 & Low SL, Low Rip Fil \\
\hline 030101030901 & 1.68127573 & 61.2 & Low SL, Low Rip Fil \\
\hline 030101030902 & 2.600373129 & 66.4 & High SL, High Rip Fil \\
\hline 030101030905 & 1.614024701 & 66.4 & Low SL, High Rip Fil \\
\hline 030101050103 & 6.769936939 & 67.5 & High SL, High Rip Fil \\
\hline 030101050104 & 5.402499345 & 66.6 & High SL, High Rip Fil \\
\hline 030101050203 & 5.761171501 & 65.1 & High SL, Low Rip Fil \\
\hline 030101050205 & 8.877135853 & 69.1 & High SL, High Rip Fil \\
\hline 030102010203 & 6.030175618 & 72.3 & High SL, High Rip Fil \\
\hline 030102010302 & 11.99310021 & 71.3 & High SL, High Rip Fil \\
\hline 030102010303 & 10.02040335 & 71.1 & High SL, High Rip Fil \\
\hline 030102010304 & 14.77280941 & 69.6 & High SL, High Rip Fil \\
\hline 030102010401 & 14.03304809 & 68.8 & High SL, High Rip Fil \\
\hline 030102010403 & 54.87683982 & 69.2 & High SL, High Rip Fil \\
\hline 030102010404 & 40.46270256 & 72.1 & High SL, High Rip Fil \\
\hline 030102010501 & 10.55841158 & 69.2 & High SL, High Rip Fil \\
\hline 030102010503 & 26.29515241 & 72.0 & High SL, High Rip Fil \\
\hline 030102010504 & 22.59634581 & 71.4 & High SL, High Rip Fil \\
\hline 030102010602 & 62.58829117 & 68.9 & High SL, High Rip Fil \\
\hline 030102010603 & 46.11178902 & 71.0 & High SL, High Rip Fil \\
\hline 030102010802 & 32.07874093 & 74.8 & High SL, High Rip Fil \\
\hline 030102010901 & 25.5778081 & 74.7 & High SL, High Rip Fil \\
\hline 030102010905 & 20.35464484 & 74.3 & High SL, High Rip Fil \\
\hline 030102011201 & 88.18851628 & 70.3 & High SL, High Rip Fil \\
\hline
\end{tabular}

We assigned one of four categories to each HUC-12: (1)High SL, High Rip Fil, (2) High SL, Low Rip Fil, (3) Low SL, High Rip Fil, or (4) Low SL, Low Rip Fil based on the observed data distribution to have similar representation from each category 
Table 4 A list of all 30 field sites is shown along with geospatial coordinates and location descriptions

\begin{tabular}{|c|c|c|c|c|}
\hline Site & location & Latitude & Longitude & Reach length (m) \\
\hline 1 & North Fork Roanoke River at North Fork Road & 37.18775 & -80.35233 & 833 \\
\hline 2 & North Fork Roanoke River at Lee Highway/US11 & 37.26750 & -80.02666 & 1410 \\
\hline 3 & Tinker Creek at Glade Road & 37.27722 & -79.90916 & 1050 \\
\hline 4 & Goose Creek at Chellis Ford Road & 37.11646 & -79.38715 & 1031 \\
\hline 5 & Cherrystone Creek at CR703 & 36.81413 & -79.35081 & 704 \\
\hline 6 & Mayo River at Anglin Mill Road & 36.53717 & -79.98922 & 325 \\
\hline 7 & Big Otter Creek at Claytor Mill Road & 37.27613 & -79.43376 & 561 \\
\hline 8 & Smith River at Field Avenue & 36.70083 & -79.93333 & 634 \\
\hline 9 & Runnett Bag Creek at SR40 & 36.88396 & -80.14918 & 615 \\
\hline 10 & Smith River at CR704 & 36.80527 & -80.20078 & 479 \\
\hline 11 & Sappony Creek at CR681 & 36.94323 & -77.45246 & 777 \\
\hline 12 & Nottoway River at CR630 & 36.84801 & -77.49246 & 909 \\
\hline 13 & Banister River at Johnson Mill Road & 36.89620 & -79.22602 & 715 \\
\hline 14 & Little Falling River at Down Creek Road & 37.11687 & -78.93145 & 768 \\
\hline 15 & Rocky Run Creek at Glebe Road & 37.07238 & -77.67800 & 641 \\
\hline 16 & Stony Creek at Courthouse Road/CR619 & 37.055681 & -77.5706 & 472 \\
\hline 17 & Big Otter River at Wyatt's Way/SR24 & 37.24593 & -79.34951 & 1068 \\
\hline 18 & Tinker Creek at Hollins Road & 37.32223 & -79.93123 & 741 \\
\hline 19 & Stony Creek at Troublefield Road & 36.97047 & -77.44993 & 1107 \\
\hline 20 & Sturgeon Creek at Cherry Hill/Cut Bank Road & 36.90143 & -77.67360 & 811 \\
\hline 21 & Elliot Creek at Alleghany Spring Road & 37.127347 & -80.265994 & 420 \\
\hline 22 & Mason Creek at Roanoke Boulevard & 37.27304 & -80.02962 & 620 \\
\hline 23 & South Fork Roanoke River at Allenghany Spring Road & 37.12728 & -80.265914 & 360 \\
\hline 24 & Glade Creek at Glade Road & 37.277272 & -79.908603 & 600 \\
\hline 25 & Beaverdam Creek at Fisherman Cove off Goodview Road & 37.224978 & -79.750769 & 500 \\
\hline 26 & $\begin{array}{l}\text { Bradshaw Creek at confluence with N. Fork Roanoke River off } \\
\text { North Fork Road }\end{array}$ & 37.23441 & -80.25514 & 245 \\
\hline 27 & Blackwater River at SR122/Booker T Washington Highway & 37.04262 & -79.84228 & 550 \\
\hline 28 & Smith River at Cory Kruse property & 36.78931 & -80.22134 & 750 \\
\hline 29 & South Mayo River at Ayers Orchard Road & 36.598 & -80.16867 & 450 \\
\hline 30 & Snow Creek at Pigg River confluence & 36.92663 & -79.59922 & 330 \\
\hline
\end{tabular}

Reach lengths were measured in the field

US United States highway

$C R$ county route

$S R$ state route

Table 5 Resulting equations (Eq.s) from our multiple linear regression (MLR) models

\begin{tabular}{llll}
\hline & Watershed Scale Eq. & Huc-12 Scale Eq. & Reach Scale Eq. \\
\hline \% Silt cover & $\%$ Silt $=(-1.556 * \mathrm{RF})+145.8107$ & $\%$ Silt $=(-0.0005833 * \mathrm{Ar})+$ & $\%$ Silt $=(-0.3294 * \mathrm{SL})+(-0.34965 * \mathrm{RF})+$ \\
& & $(-1.445 * \mathrm{RF})+152.7$ & $(0.04538 *$ Precip $)+58.01186$ \\
\% Embeddedness & $\% \mathrm{Emb}=(-3.08908 * \mathrm{RF})+(0.71498 * \mathrm{Slp})+$ & $\%$ Emb $=(-1.38511 * \mathrm{SL})+$ & $\%$ Emb $=(0.002492 * \mathrm{Ar})+(-0.6869 * \mathrm{SL})+$ \\
& $(0.20483 *$ Precip $)+(-0.33055 * \mathrm{Txt})+165.51557$ & $(0.15684 *$ Precip $)+(-11.42258)$ & $(0.112761 *$ Precip $)+(-0.194266 * \mathrm{Txt})+13.829964$ \\
\hline
\end{tabular}

Each equation represents the MLR model with the lowest AIC value. Equations can be used to estimate percent silt cover and percent embeddedness of stream substrates

$R F$ Riparian filtration (\%)

Slp slope (\% rise)

Precip precipitation (mm/unit time)

Txt silty-textured soils (\% area of watershed unit)

$A r$ area (hectares)

$S L$ soil loss (tonnes per hectare per year) 
Table 6 Annual soil loss calculations in tonnes per hectare per year are shown in the table below

\begin{tabular}{|c|c|c|c|c|}
\hline \multirow[b]{2}{*}{ Site } & \multirow[b]{2}{*}{ Location } & \multicolumn{3}{|c|}{$\begin{array}{l}\text { Annual soil loss (tonnes hec } \\
-1 \text { year }^{-1} \text { ) }\end{array}$} \\
\hline & & Watershed & Huc-12 & Reach \\
\hline 1 & North Fork Roanoke River at North Fork Road & 3.7 & 4.6 & 2.3 \\
\hline 2 & North Fork Roanoke River at Lee Highway/US11 & 2.3 & 1.3 & 0.9 \\
\hline 3 & Tinker Creek at Glade Road & 0.8 & 1.9 & 1.0 \\
\hline 4 & Goose Creek at Chellis Ford Road & 2.6 & 2.3 & 1.6 \\
\hline 5 & Cherrystone Creek at CR703 & 4.6 & 5.4 & 5.1 \\
\hline 6 & Mayo River at Anglin Mill Road & 2.4 & 1.3 & 2.8 \\
\hline 7 & Big Otter Creek at Claytor Mill Road & 3.4 & 3.1 & 7.5 \\
\hline 8 & Smith River at Field Avenue & 1.5 & 1.7 & 2.1 \\
\hline 9 & Runnett Bag Creek at SR40 & 1.5 & 1.3 & 1.3 \\
\hline 10 & Smith River at CR704 & 1.2 & 1.2 & 1.0 \\
\hline 11 & Sappony Creek at CR681 & 60.1 & 62.5 & 141.7 \\
\hline 12 & Nottoway River at CR630 & 25.8 & 54.8 & 34.8 \\
\hline 13 & Banister River at Johnson Mill Road & 6.0 & 5.8 & 1.8 \\
\hline 14 & Little Falling River at Down Creek Road & 5.3 & 3.9 & 6.1 \\
\hline 15 & Rocky Run Creek at Glebe Road & 19.9 & 26.3 & 18.8 \\
\hline 16 & Stony Creek at Courthouse Road/CR619 & 20.0 & 22.6 & 49.1 \\
\hline 17 & Big Otter River at Wyatt's Way/SR24 & 4.2 & 6.3 & 4.5 \\
\hline 18 & Tinker Creek at Hollins Road & 2.5 & 2.6 & 2.1 \\
\hline 19 & Stony Creek at Troublefield Road & 71.0 & 46.1 & 21.0 \\
\hline 20 & Sturgeon Creek at Cherry Hill/Cut Bank Road & 8.2 & 14.8 & 0.9 \\
\hline 21 & Elliot Creek at Alleghany Spring Road & 4.3 & 4.8 & 2.0 \\
\hline 22 & Mason Creek at Roanoke Boulevard & 0.6 & 1.1 & 1.7 \\
\hline 23 & South Fork Roanoke River at Allenghany Spring Road & 2.5 & 1.2 & 3.4 \\
\hline 24 & Glade Creek at Glade Road & 2.5 & 1.9 & 0.6 \\
\hline 25 & Beaverdam Creek at Fisherman Cove off Goodview Road & 1.5 & 1.1 & 0.9 \\
\hline 26 & $\begin{array}{l}\text { Bradshaw Creek at confluence with N. Fork Roanoke River off North } \\
\text { Fork Road }\end{array}$ & 1.2 & 2.1 & 2.0 \\
\hline 27 & Blackwater River at SR122/Booker T Washington Highway & 3.1 & 3.3 & 1.8 \\
\hline 28 & Smith River at Cory Kruse property & 1.3 & 1.5 & 0.5 \\
\hline 29 & South Mayo River at Ayers Orchard Road & 1.3 & 1.4 & 1.1 \\
\hline 30 & Snow Creek at Pigg River confluence & 3.9 & 3.5 & 0.5 \\
\hline
\end{tabular}

We calculated values at three spatial scales using the Revised Universal Soil Loss Equation (RUSLE). The full RUSLE calculates annual soil erosion (A) in tonnes per hectare per year with inputs of soil erosivity (Rfactor), soil erodibility (K-factor), length-slope calculations (LS-factor), cover management practices (Cfactor) and the practice factor (P-factor; assumed to be 1) (Lim et al. 2005) 
Table 7 Each of our 30 study sites were ranked based on observed silt cover and embeddedness

\begin{tabular}{|c|c|c|c|c|c|c|c|c|}
\hline \multirow[b]{2}{*}{$\begin{array}{l}\text { Site } \\
\text { Number }\end{array}$} & \multicolumn{4}{|c|}{ Silt Cover Ranking } & \multicolumn{4}{|c|}{ Embeddedness Ranking } \\
\hline & $\begin{array}{l}\text { Observed } \\
\text { Silt Cover }\end{array}$ & Watershed & HUC-12 & Reach & $\begin{array}{l}\text { Observed } \\
\text { Embeddedness }\end{array}$ & Watershed & HUC-12 & Reach \\
\hline 1 & 10 & 6 & 19 & 20 & 12 & 30 & 27 & 16 \\
\hline 2 & 14 & 5 & 10 & 10 & 18 & 20 & 26 & 27 \\
\hline 3 & 12 & 2 & 3 & 15 & 20 & 13 & 24 & 20 \\
\hline 4 & 28 & 14 & 13 & 21 & 26 & 17 & 14 & 28 \\
\hline 5 & 11 & 16 & 21 & 19 & 21 & 19 & 15 & 17 \\
\hline 6 & 3 & 13 & 16 & 3 & 10 & 14 & 17 & 8 \\
\hline 7 & 19 & 4 & 9 & 25 & 13 & 8 & 13 & 18 \\
\hline 8 & 20 & 17 & 14 & 16 & 15 & 22 & 19 & 19 \\
\hline 9 & 22 & 21 & 15 & 24 & 28 & 24 & 20 & 25 \\
\hline 10 & 27 & 19 & 27 & 18 & 25 & 11 & 16 & 14 \\
\hline 11 & 29 & 25 & 17 & 29 & 30 & 18 & 30 & 29 \\
\hline 12 & 30 & 28 & 30 & 27 & 29 & 27 & 29 & 26 \\
\hline 13 & 23 & 15 & 8 & 23 & 27 & 15 & 12 & 21 \\
\hline 14 & 18 & 22 & 25 & 17 & 14 & 23 & 5 & 15 \\
\hline 15 & 17 & 30 & 18 & 28 & 17 & 28 & 23 & 23 \\
\hline 16 & 15 & 26 & 26 & 30 & 23 & 25 & 18 & 30 \\
\hline 17 & 25 & 11 & 20 & 22 & 22 & 10 & 11 & 24 \\
\hline 18 & 7 & 1 & 1 & 7 & 11 & 6 & 22 & 10 \\
\hline 19 & 16 & 27 & 29 & 26 & 19 & 29 & 28 & 22 \\
\hline 20 & 13 & 29 & 28 & 12 & 16 & 26 & 10 & 6 \\
\hline 21 & 21 & 12 & 11 & 14 & 24 & 16 & 25 & 12 \\
\hline 22 & 5 & 8 & 6 & 1 & 8 & 9 & 3 & 3 \\
\hline 23 & 9 & 20 & 7 & 8 & 6 & 12 & 21 & 13 \\
\hline 24 & 2 & 3 & 2 & 2 & 4 & 2 & 6 & 11 \\
\hline 25 & 1 & 7 & 4 & 11 & 2 & 7 & 8 & 4 \\
\hline 26 & 6 & 24 & 5 & 4 & 9 & 21 & 7 & 9 \\
\hline 27 & 4 & 10 & 22 & 13 & 3 & 5 & 9 & 7 \\
\hline 28 & 24 & 23 & 24 & 9 & 7 & 3 & 2 & 5 \\
\hline 29 & 26 & 18 & 23 & 5 & 5 & 1 & 1 & 1 \\
\hline 30 & 8 & 9 & 12 & 6 & 1 & 4 & 4 & 2 \\
\hline
\end{tabular}

We then ranked sites based on predicted silt cover and embeddedness from multiple linear regression models at all three spatial scales. Sites were ranked in decreasing order of observed and predicted silt conditions

\section{References}

Abrahart RJ, White SM (2001) Modeling sediment transfer in Malawi: Comparing backpropagation neural network solutions against a multiple linear regression benchmark using small datasets. Phys Chem Earth Part B 26(1):19-24. https://doi.org/10.1016/S14641909(01)85008-5

Bain MB, Stevenson NJ (1999) Aquatic habitat assessment: common methods. American Fisheries Society, Bethesda, MD

Beschta RL, Jackson WL (1979) The intrusion of fine sediments into a stable gravel bed. J Fish Res Board Can 36(2):204-210. https:// doi.org/10.1139/f79-030

Bilotta G, Brazier R (2008) Understanding the influence of suspended solids on water quality and aquatic biota. Water Res 42 (12):2849-2861. https://doi.org/10.1016/j.watres.2008.03.018

Boardman J and Favis-Mortlock D (2001) How will future climate change and land-use change affect rates of erosion on agricultural land? In: Ascough II JC and Flanagan DC (eds) Soil Erosion Res for the 21st Century, Proc. Int. Symp. ASABE, Honolulu, HI, USA pp 498-501

Borselli L, Cassi P, Torri D (2008) Prolegomena to sediment and flow connectivity in the landscape: a GIS and field numerical assessment. Catena 75:268-277

Brady N and Weil R (2008) The nature and properties of soils (14th ed). Pearson. Columbus, $\mathrm{OH}$

Castelle AJ, Johnson AW, Conolly C (1993) Wetland and stream buffer size requirements—a review. J Env Qual 23(5):878-882. https://doi.org/10.2134/jeq1994.00472425002300050004x

Chengfu Z, Sheng L, Junyu Q, Zisheng X, Fanrui M (2016) Assessing impacts of riparian buffer zones on sediment and nutrient loadings into streams and watershed scale using an integrated REMM-SWAT model. Hydrol Process 31:916-924. https://doi. org/10.1002/hyp.11073

Christensen J, Hewitson B, Busuioc A, Chen A, Gao X, Held I, Jones R, Kolli R, Kwon W, Laprise R, Magaa Rueda V, Mearns L, Menndez C, Risnen J, Rinke A, Sarr A, Whetton P (2007) 
Regional climate projections. In: Solomon S, Qin D, Manning M, Chen Z, Marquis M, Averyt KB, Tignor M, Miller HL (eds.) Climate change 2007: the physical science basis. Contribution of Working Group I to the Fourth Assessment Report of the Intergovernmental Panel on Climate Change. Cambridge University Press, Cambridge, United Kingdom and New York, NY, USA

Department of Conservation and Recreation (DCR) (2004) The Virginia stream restoration and stabilization bestmanagement practices guide. DCR, Richmond, VA

De Rosa P, Cencetti C and Fredduzzi A (2016) A GRASS tool for the Sediment Delivery Ratio mapping. PeerJ "Preprints". https://doi. org/10.7287/peerj.preprints.2227v2

Dingman SL (2008) Physical hydrology, 2nd ed. Waveland Press, Long Grove, Ill

GEI Consultants Inc (2002) Efficacy and economics of riparian buffers on agricultural lands. Washington Agricultural Caucus, Moxee, WA

Griensven AV, Maharjan S, and Alemayehu T (2014) Improved simulation of evapotranspiration for land use and climate change impact analysis at catchment scale. International Congress on Environmental Modelling and Software. Paper 14. http://schola rsarchive.byu.edu/iemssconference/2014/Stream-E/14. https:// gdg.sc.egov.usda.gov/GDGOrder.aspx ?order $=$ QuickState Accessed March 2016

Haag WR, Williams JD (2013) Biodiversity on the brink: an assessment of conservation strategies for North American freshwater mussels. Hydrobiologia 735(1):45-60. https://doi.org/10.1007/ s10750-013-1524-7

Hair JF, Black WC, Babin BJ, Anderson RE (1995) Multivariate Data Analysis, 7th ed. Macmillan, New York, NY

Henley J, Natural Resource Conservation Service and US Geological Survey (2006) HUC-12 Watershed Boundary Dataset for Virginia. https://gdg.sc.egov.usda.gov/GDGOrder.aspx?order= QuickState Accessed May 2014

Holmes TP, Bergstrom JC, Huszar E, Kask SB, Orr III F (2004) Contingent valuation, net marginal benefits, and the scale of riparian ecosystem restoration. Ecol Econ 49(1):19-30. https:// doi.org/10.1016/j.ecolecon.2003.10.015

Homer CG, Dewitz JA, Yang L, Jin S, Danielson P, Xian G, Coulston J, Herold ND, Wickham JD, Megown K (2015) Completion of the 2011 National Land Cover Database for the conterminous United States-representing a decade of land cover change information. Photogramm Eng Remote Sens 81(5):345-354

Hooke JM (1979) An analysis of the processes of river bank erosion. J Hydrol 42(1-2):39-62. https://doi.org/10.1016/0022-1694(79) 90005-2

Independent Petroleum Association of America (2004) Guidance document: reasonable and prudent practices for stabilization (RAPPS) of oil and gas construction sites (Appendix A) (Tech). https://fracfocus.org/sites/default/files/publications/rapps_guida nce.pdf Accessed June 2014

Jack KB, Leimona B, Ferraro P (2008) A revealed preference approach to estimating supply curves for ecosystem services: use of auctions to set payments for soil erosion control in Indonesia. Conserv Biol 23(2):359-367. https://doi.org/10.1111/j.15231739.2008.01086.x

James LA (2013) Legacy sediment: definitions and processes of episodically produced anthropogenic sediment. Anthropocene 2:16-26. https://doi.org/10.1016/j.ancene.2013.04.001

Jastram J, Krstoloic JL, Moyer DL and Hyer KE (2015) Fluvial geomorphology and suspended-sediment transport during construction of the Roanoke River Flood Reduction Project in Roanoke, Virginia, 2005-2012. US Dept of the Interior and US Geological Survey Scientific Investigations Report 2015-5111. https://pubs.er.usgs.gov/publication/sir20155111 Accessed May 2016
Jelks HL, Walsh SJ, Burkhead NM, Contreras-Balderas S, Diaz-Pardo E, Hendrickson DA, Lyons J, Mandrak NE, McCormick F, Nelson JS, Platania SP, Porter BA, Renaud CB, Schmitter-Soto JJ, Taylor EB, Warren Jr. ML (2008) Conservation status of imperiled North American freshwater and diadromous fishes. Fisheries 33(8):372-407

Jones KB, Neale AC, Nash MS, Van Remortel RD, Wickham JD, Ritters KH, O'Neil RV (2001) Predicting nutrient and sediment loadings to streams from landscape metrics: a multiple watershed study from the United States Mid-Atlantic Region. Landsc Ecol 16:301-312

Jabbar M (2003) Application of GIS to estimate soil erosion using RUSLE Geo-spatial Information Science 6(1):34-37

Lee GS and Lee KH (2010) Determining the sediment delivery ratio using the sediment-rating curve and a geographic information system-embedded soil erosion model on a Basin Scale. J Hydrol Eng. https://doi.org/10.1061/(ASCE)HE.1943-5584.0000254

Levasseur M, Bergeron NE, Lapointe MF, Berube F (2006) Effects of silt and very fine sand dynamics in Atlantic salmon (Salmo salar) redds on embryo hatching success. Can J Fish Aquat Sci 63 (7):1450-1459. https://doi.org/10.1139/f06-050

Lim K, Sagong M, Engel B, Tang Z, Choi J, Kim K (2005) GIS-based sediment assessment tool. CATENA 64(1):61-80. https://doi.org/ 10.1016/j.catena.2005.06.013

The Louis Berger Group (2006) Benthic TMDL development for the Roanoke River, Virginia, Virginia Department of Environmental Quality (VADEQ). http://www.deq.virginia.gov/portals/0/DEQ/ Water/TMDL/apptmdls/roankrvr/uroanbc.pdf Accessed October 2015

Lu H, Moran CJ, Prosser IP (2006) Modelling sediment delivery ratio over the Murray Darling Basin. Env Model Softw 21 (9):1297-1308. https://doi.org/10.1016/j.envsoft.2005.04.021

Matthies M, Giupponi C, Ostendorf B (2007) Environmental decision support systems: current issues, methods and tools. Environ Model Softw 22(2):123-127. https://doi.org/10.1016/j.envsoft. 2005.09.005

Mayer PM, Reynolds SK, McCutchen MD, Canfield TJ (2007) Metaanalysis of nitrogen removal in riparian buffers. J Environ Qual 36(4):1172-1180. https://doi.org/10.2134/jeq2006.0462

Milhous RT (1998) Modelling of instream flow needs: The link between sediment and aquatic habitat. Regul River Res Manag 14 (1):79-94. https://doi.org/10.1002/(SICI)1099-1646(199801/02) 14:13.0.CO;2-9

Mohamadi MA, Kavian A (2015) Effects of rainfall patterns on runoff and soil erosion in field plots. Int Soil Water Conserv Res 3 (4):273-281. https://doi.org/10.1016/j.iswcr.2015.10.001

Montgomery DR, Buffington JM (1997) Channel-reach morphology in mountain drainage basins. GSA Bull 109(5):596-611. https://doi. org/10.1130/0016-7606(1997)109<0596:CRMIMD>2.3.CO;2

Novotny N (2003) Water quality: diffuse pollution and watershed management. John Wiley \& Sons. Boston, MA

Peay S (2002) Guidance on habitat for the White-clawed Crayfish and its restoration. Species Recovery Program, Report W1-067/TR. English Nature and the Environment Agency. https://www.gov. uk/government/uploads/system/uploads/attachment_data/file/ 290346/sw1-067-tr-e-e.pdf Accessed March 2016

Perry LG, Reynolds LV, Beechie TJ, Collins MJ, Shafroth PB (2015) Incorporating climate change projections into riparian restoration planning and design. Ecohydrology 8(5):863-879. https://doi.org/ 10.1002/eco.1645

PRISM Climate Group Oregon State University (2014-2015) PRISM datasets for US monthly precipitation 2014-2015. http://prism. oregonstate.edu/recent/ Accessed January 2016

Renard K, Foster G, Weesies G, McCool D, Yoder D (1997) Predicting soil erosion by water: a guide to conservation planning with the revised universal soil loss equation (RUSLE). 
Agriculture handbook number 703. US Dept of Agriculture Agricultural Research Service.Washington DC

Rickson RJ (2014) Can control of soil erosion mitigate water pollution by sediments? Sci Total Environ 468-469:1187-1197. https://doi. org/10.1016/j.scitotenv.2013.05.057

Rosenberger A, Angermeier P (2003) Ontogenetic shifts in habitat use by the endangered Roanoke logperch (Percina rex). Freshw Biol 48 (9):1563-1577. https://doi.org/10.1046/j.1365-2427.2003.01109.x

Schaetzl RJ, Anderson S (2005) Soils: genesis and geomorphology. Cambridge University Press, Cambridge, UK

Seelbach PW, Hinz LC, Wiley MJ, and Cooper AR (2011) Use of multiple linear regression to estimate flow regimes for all rivers across Illinois, Michigan, and Wisconsin. Michigan Department of Natural Resources Fisheries Division Report 2095. https://www.michigan.gov/documents/dnr/RR2095_362496_7. pdf Accessed April 2016

Smith G, Pun A (2010) How does Earth work? Physical geology and the process of science. Pearson, Upper Saddle River, NJ

Soil Survey Staff, Natural Resources Conservation Service, United States Department of Agriculture (2015) Soil Survey Geographic (SSURGO) Database. https://sdmdataaccess.sc.egov.usda.gov. Accessed August 2015-2016

Sprague Ralph H (1980) A Framework for the Development of Decision Support Systems MIS Quarterly 4(4):1

Sutherland A, Meyer J, Gardiner E (2002) Effects of land cover on sediment regime and fish assemblage structure in four southern Appalachian streams. Freshw Biol 47(9):791-805. https://doi.org/ 10.1046/j.1365-2427.2002.00927.x

Trabucchi M, Comin F, O'Farrell P (2013) Hierarchical priority setting for restoration in a watershed in NE Spain, based on assessments of soil erosion and ecosystem services. Reg Environ Change 13 (4):911-926. https://doi.org/10.1007/s10113-012-0392-4

Tufekcioglu A, Raich JW, Isenhart TM, Schultz RC (2001) Soil respiration within riparian buffers and adjacent crop fields. Plant Soil 229(1):117-124. https://doi.org/10.1023/A:1004818422908

Underwood J, Renshaw G, Magilligan F, Dade W, Landis J (2015) Join isotopic mass balance: a novel approach to quantifying channel bed to channel margins sediment transfer during storm events. Earth Surf Process Landf 40(12):1563-1573. https://doi. org/10.1002/esp. 3734
US Dept of Agriculture Natural Resource Conservation Service (2010) $30 \mathrm{~m}$ resolution digital elevation model for Virginia. Geospatial Data Gateway. https://gdg.sc.egov.usda.gov/ Accessed June 2014

US Fish and Wildlife Service and US National Oceanic and Atmospheric Administration (2016) Habitat conservation planning and incidental take permit processing handbook. https://www.fws. gov/endangered/esa-library/pdf/HCP_Handbook-CoverExecutiveSummary.pdf. Accessed April 2017

VA Department of Conservation and Recreation (2017) Program year 2018 Virginia agricultural cost-share (VACS) BMP manual. http://dswcapps.dcr.virginia.gov/htdocs/agbmpman/csmanual.pdf Accessed January 2016

VA Department of Environmental Quality, VA Department of Conservation Resources and Virginia Department of Health (2014) Virginia water quality assessment 305(b)/303(d) integrated report. http://www.deq.virginia.gov/Portals/0/DEQ/Water/Wa terQualityAssessments/IntegratedReport/2014/ir14_Integrated_ Report_Final.pdf Accessed October 2015

VA Department of Forestry (2011) Virginia's forestry best management practices for water quality. Technical Manual. http://dof. virginia.gov/infopubs/BMP-Technical-Guide_pub.pdf Accessed January 2016

Van Rompaey AJ, Verstraeten G, Van Oost K, Govers G, Poesen J (2001) Modelling mean annual sediment yield using a distributed approach. Earth Surf Process Landf 26(11):1221-1236. https:// doi.org/10.1002/esp. 275

Villamagna A, Scott L, Gillespie J (2015) Collateral benefits from public and private conservation lands: a comparison of ecosystem service capacities. Environ Conserv 42(3):204-215. https://doi. org/10.1017/S0376892914000393

Woo HS, Julien PY, ASCE M, Richardson EV, ASCE F (1986) Washload and fine sediment load. J Hydraul Eng 112 (6):541-545. https://doi.org/10.1061/(ASCE)0733-9429(1986) $112: 6(541)$

Zhang X, Srinivasan R, Arnold J, Izaurralde RC, Bosch D (2011) Simultaneous calibration of surface flow and baseflow simulations: a revisit of the SWAT model calibration framework. Hydrol Process 25(14):2313-2320. https://doi.org/10.1002/hyp. 8058 